\title{
LEIJONHUFVUD'S INTERPRETATION OF J.M.KEYNES (MONETARY ECONOMICS) REVISITED
}

\author{
LETUNIC, S. \& DRAGICEVIC, M.
}

Abstract: Liberation from Say's law (by Keynes) resulted in macroeconomics as economics sub-discipline. Keynes's „, General theory“ can be regarded as a special case of the Classical theory. At Keynes present are two revolutions. Consequences of the General Theory were to establish "Keynesianism" as a third body of analysis antithetical to traditional monetary approaches and unrelated to value theory. In general competitive equilibrium theory present is "absence of money illusion". Keynes' diagnosis of depressions is - the general level of long-term asset prices is lower than warranted. Keynes assumes that wealth effect affects current consumption in the same direction as the substitution effect. Speculative activity plays large role. Keynes' critics have cast him in the mold of a "static and non-historical" system. At Neo - Keynesianism premise is that there are institutional barriers to prices flexibility which lead to imbalance vectors.

Key words: Keynes, (Neo) Classicals, Monetary Theory, Price Vector, NeoKeynesianism
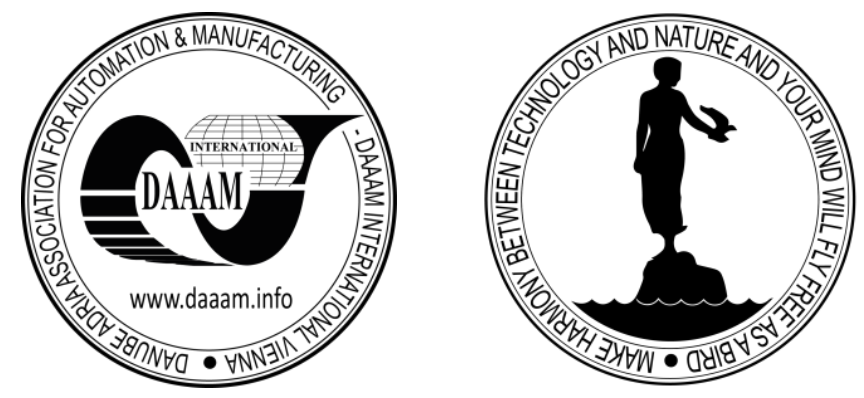

Authors' data: Dr. Sc. Letunic S[tijepo] ; Dr. Sc. Dragicevic M[arija], University of Dubrovnik, Department of Economics and Business Economics. Lapadska obala 7, 20000 Dubrovnik, Croatia, stijepo.letunic@du.t-com.hr, marija.dragicevic@unidu.hr

This Publication has to be referred as: Letunic, S[tijepo] \& Dragicevic, M[arija] (2015). Leijonhufvud's Interpretation of J.M.Keynes (Monetary Economics) Revisited, Chapter 03 in DAAAM International Scientific Book 2015, pp.031-038, B. Katalinic (Ed.), Published by DAAAM International, ISBN 978-3-902734-05-1, ISSN 17269687, Vienna, Austria

DOI: $10.2507 /$ daaam.scibook.2015.03 


\section{Introduction}

The First World War brought many changes and also to economic science and analysis. A big influence after the First World War has J.M. Keynes. With depression in America, classic orthodoxy has found no answer, and while temporary stoppages were respected, six long years of depression was too much. In those circumstances, Keynes' theory downs classical beliefs (Keynesian revolution). Great depression showed all weaknesses of the classical model that has until then been the basic economic model. J.M.Keynes gave a new look to the balance in the economy and the impact of economic policy on it. On the basis of research results, using the methods of desk research and synthesis, the aim of this paper is to point out Leijonhufvud's interpretation of interaction of real and monetary phenomena at Keynes, together with important foregoing and newer development on this subject.

\section{Pre-keynesian economics related subject}

T.Malthus (Dupaquier et al, 2001) doubted Say's law and considered the possibility of overproduction. For the first time in the English economic theory the potential crisis that stems from causes inherent in the capitalist system has been recognized. Say's thought for a century was the key to understanding of classics in relation to state economic policy. According to Say's law, from aggregate production (sales) stems at least as much demand for such an offer. Therefore it cannot possibly come to insufficient demand. Savings would be re-invested, and even if not invested, prices are adjusted downward by adjusting to lower income. Therefore any management of the central bank is not necessary. Only Keynes had suppressed this dogma (Schumpeter, 1975). Liberation from Say's law and the affirmation of demand management resulted in macroeconomics as economics sub-discipline.

In Germany during this period British economists were criticized. Identification with the "historical economics" implies criticism of the prevailing orthodoxy (in economics) and can be dated by the early 19th century. Economist A.Müller considered the state as not only a basic human need but as the greatest human need. German economist F.List held that the state has an indispensable role from the initial to the later stages of the economy and the final balance between agriculture, industry and trade (Schumpeter, 1975).

According to V.Pareto's opinion (Eisermann et al, 2001) economics as a science should be separated from issues such as justice and injustice, suffering and distress, and the like. This could be also explained as a way of escape from responsibility and guilt for the system originated in the classical tradition (Schumpeter, 1975). The foundations of neoclassical economics are set at the end of the 19th century, its progress and improvement continued in the 20th century, until the present day (Sharma, 2010).

An important critic of the classical system was Norwegian economist T.Veblen (Hodgson, 2004) according to which the economic man in the classical system that carefully accounts and seeks to achieve maximum pleasure, is artificial creation and his motivation is much more complex. 
The origins of the welfare state (often used by those hostile to state intervention) are linked to Germany during Bismarck who sought to mitigate the most serious cruelties of capitalism, which was done by passing a law for insurance in case of accidents, illness, old age and disability. In England, under the guidance of the then Minister of Finance L.George, laws on regulating compensation during illness, and later unemployment were adopted. Privileged in society could not easily grasp it. Such an example later will follow USA (Schumpeter, 1975).

A.Marshall (Whitaker et al, 2001) had a dominant influence on the economics of the English-speaking world before the Great Depression in 1930s. His doctrines advocated laissez-faire; attitude that government intervention in the economy, no matter how well-intentioned, can do more harm than good; faith in free market natural tendency to balance and that at the level of real wages in correspondence with full employment; belief in the positive effects of free trade; representation of the gold standard and sound public finances (Sharma, 2010). An interesting theory is by Marshall's successor A.C.Pigou that the theory of marginal utility in the classic sense, which says that the marginal utility of additional money for the individual does not decrease with wealth explained differently, and said that total pleasures the system provides increase with the transfer of resources from rich to poor. His position later remained controversial, but has given substantial support to the policy of redistribution of income.

In the 20th century the strong support of liberalism (neoclassical thought and based on it the ideology of neo-liberalism) give classics L.Mises and F.Hayek. Hayek is one of the main authors of the movement for the abolition of the welfare state at the same time insisting on the inseparability of economic (Lawson R.A., \& Clark J.R., 2010) from genuine freedom (Mises, L.v. \& Hayek, F.A., 1998), (freedom of course understood inside the limits of liberal social theory, not freedom as innate possibility inherent to humankind, Veljak, 2009). His position represents a confirmation of what was the original core of classical liberalism, which is the theory of limitation of government power. Since liberalism is based on voluntarity, every individual alone should decide what actually is of concern to him, by what obtains the "right to privacy". Liberalism believes that the state has no higher purpose than the welfare of individuals as they determine it, what in the philosophy at the notion of human freedom already stated J.S. Mill (Cakardic, 2006). In his opinion it is impossible to determine once and for all the boundary between state power and individual rights (Bobbio, 1992). To that classical liberalism generally knew the answer: the boundaries of my freedom and my (otherwise inalienable) human rights are bordered with the freedom of others and the rights of others to enjoy equal freedom as those belonging to me (Veljak, 2010). Hayek $\mathrm{s}$ "holistic" approach is not easily translated into formal economic models, "but if the relevance instead of exactness becomes a benchmark for assessing the contribution to economics, then Hayek is one of the few economists whose influence on economics is growing" (Voigt, 2001).

After the First World War, it could have been even said from the standpoint of classical and neoclassical economists that industrial society has adopted a fully developed welfare state and that by bourgeois economists. In Sweden, in the conflict primarily between Wicksell and orthodox Cassel subsequent social security system has 
been developed. In Sweden, before Keynes, the state budget has been used to boost employment and demand. In those circumstances, Keynes' theory downs classical beliefs in terms of recall of Say's law, deficit spending, unemployment equilibrium (Schumpeter, 1975).

\section{Keynesian revolution and monetary theory}

In one way Keynes' „General theory“ can be regarded as a special case of the Classical theory, obtained by imposing certain restrictive assumptions on the latter. Characteristic is disaggregation of total output into consumer goods and investment good (Leijonhufvud, 1968). At Keynes present are two revolutions: The explanation of sustained and substantial unemployment, and then the attack on the received Theory of Money as a tool for the analysis of short-run problems. Relative prices do not stay constant as "the" price level adjusts (Leijonhufvud, 1983). Keynes' partially took over the definition of "saving" as "nonconsumption":

a) Saving and investment determine income, and not the interest rate

b) Liquidity preference (and the supply of money) determines the interest rate, and not money income

Both statements were aimed to dramatize his departures from received doctrine. Keynes envisaged a grand synthesis of the theory of value and the theory of money, but the actual consequences of the General Theory, however, were to establish "Keynesianism" as a third body of analysis antithetical to traditional monetary approaches and unrelated to value theory (Leijonhufvud, 1968).

In the short run, the "Classical" system adjusts to changes in money expenditures by means of price-level movements while Keynesian adjusts primarily by way of real income movements (production) (Leijonhufvud, 1983). In the Keynesian tradition, the money price level and interest rates are usually considered variable. In short term Keynes considered consumption (saving), investment, and employment are freely variable (Leijonhufvud, 1968). Mentioned is present in Keynesian original theory, but according to Leijonhufvud such a view in theory which came out after Keynes' death has been neglected.

According to Keynes, the constraint on household income, emerging through the inability of traders to sell all they want at "the" prevailing market price, leads to a reduction in effective demand in product markets with further ("multiplier") repercussions on aggregate income. "Classical" general equilibrium model, in contrast, presents the reassuring picture of an economic system equipped exclusively with deviation-counteracting feedback mechanisms.

In the Keynesian macro-system the Marshallian ranking of price and quantity adjustment speeds is reversed. The "revolutionary" element in the Keynesian economics can perhaps not be stated in simpler terms (Leijonhufvud, 1968).

Important question is of expected and realized results "overlapping" since current production cannot be guided by what amounts to perfect foreknowledge, but must be based on expectations. The price actually achieved depends upon the amount of information "purchased" (analysis of the behavior of the individual trader at information-gathering). 
By contrast in general competitive equilibrium all goods are perfectly liquid (Leijonhufvud, 1968). In such economic theory present is "absence of money illusion" (Lewbel, 1990) where nominal values are divided with the GNP-deflator. Clower's term "notional" excess demand is where the trader is able to realize any sales he desires at the announced price vector, while at function of effective excess demand trader takes into account constraints on the transactions quantities that people expect to be able to realize. Dynamic properties of an economic system depend upon, as Leijonhufvud calls it, its "transaction structure", i.e. money since marginal product of labor cannot be payed with „cold-pressed steel “ (Leijonhufvud, 1983). But, the modern version of the classical tradition(since Pigou), is that money makes no real difference except frictionally, and that the theory of production and employment can be worked out as being based on "real" exchanges. For aggregate demand functions and construction of macro-models, the necessary assumption generally is that all transactors have utility functions of the same form. Hence market excess demands-and the equilibrium solution for the system-will be unaffected. These conditions imposed on "tastes" permit total demand to be written as a function of total "income", regardless of the distribution of that income among households (Leijonhufvud, 1968). Pigou-effect points out that, in circumstances of unemployment (Leijonhufvud, 1983), at some level of money prices an excess supply of money must develop which spills over into increased demand for output. There must, then, also be one level of money prices low enough for real demand for output to correspond to full employment. In a situation of actual or threatening contraction, the ruling price vector differs from the appropriate vector. The essence of Keynes' diagnosis of depressions is this: the actual disequilibrium price vector initiating the contraction differs from the appropriate, hypothetical equilibrium vector in one major respect-the general level of long-term asset prices is lower than warranted (Leijonhufvud, 1968).

For economic analysis important is Kuznets' finding of an approximately constant long-run saving-income ratio (Cate, 2013). Keynes presumed that interest rates are inflexible in the short run and the question why the rate of interest would not "equalize saving and investment" has been one of the crucial questions of macro-dynamic theory. Keynes assumes that wealth effect affects current consumption in the same direction as the substitution effect.

Speculative activity, already in Keynes' opinion, plays an inordinately large and frequently dysfunctional role. He assumes that with appropriate institutional arrangements, the interest elasticity of money demand based purely on the "transaction and precautionary motives" would be significantly less and would not threaten with substantial ex ante hoarding. Also Keynes' speculative demand for money has been all but relinquished by modern theorists as an element of "general" macro-theory. Keynes regarded this concept as a cornerstone of his theoretical structure (Leijonhufvud, 1983).

\section{Critics and post-keynesian economics and monetary theory development}

Keynes' critics all too often have cast him in the mold of a "static and nonhistorical" system. The question is whether economic system functions more similarly to classic one (where adjustment is through prices) or Keynesian (adjustment by real 
income movements). General Theory model assumes that expectations about the longrun normal level of long rate are absolutely inelastic in the current unit period while a "modern" short-run model assumes that expectations in this regard are unit-elastic (Leijonhufvud, 1968). Later economic thought as well as the Keynesian tradition created conviction that Keynes viewed monetary policy as ineffective, but one cannot find such statement by him. That is because his views cannot be separated from the specific conditions obtaining at a particular time and place (Leijonhufvud, 1983).

One of the consequences of Keynesian revolution is that in the future the state will be responsible for the performance of the economy. In two decades after him, Keynes has the connotation of radicalism what is an indication of the rule that in the choice between disaster with the preservation of old and reforms, the first is often preferred. One of Keynes's contemporaries, A.Hansen (Samuelson, 1988), went even further than Keynes, arguing that in modern economy balance at the substantial underemployment is normal and predictable, and that it is possible to be pre-empted only by decisive action of the state (Leijonhufvud, 1983). One of the supports to Keynes' theory during the Second World War has been Kuznets' statistical model that showed the state of the economy and its possibilities more clearly.

World War II changed a lot, because during the war, many of the classic principles were ignored, also a new generation of economists grew up. Even Hayek as the fiercest critic of the intervention, did not emphasize its ineffectiveness, but a threat to freedom. Looking at the economics after Keynes, the post-war 25 years annual continuous rise of the economy, especially in the United States caused the self-congratulation of economists and taking credit. Unreadiness by the crisis in 1970s was also the result of the Keynesian theory as response to the Great Depression and not having answers to the inflation of prices and wages. Then monetarism and advocacy of classic competitive market led by Friedman gain importance (Galbraith, 1995). Also, during this period until today, economics is characterized by technicistical-mathematical approach to economics (Sharma, 2010). The period between 1930s to 1960s can be classified as belonging to classic Keynesian thought. From mid 1960s comes to the development of thought of rational expectations (Swamy, 1982), what also strengthened certain Keynesian ideas, and it comes to the neo-Keynesianism (departure from economists who represented the real business cycle; the belief is founded on the premise that there are institutional barriers to prices flexibility (Casares et al., 2014) which lead to imbalance vectors, what basically are structural issues). In that sense neoKeynesian economic theory provides alternative answers to the question of wages restrictions (in the case of asymmetry - imperfect information) - so-called wages that encourage efficiency (efficiency wages). In the models of wages that encourage efficiency (efficiency wages), employees receive wages that maximize productivity instead of being stabilized by market supply and demand. For example, in developing countries, companies can pay more than the market wage to ensure the nutrition of employees as a condition of their productivity (Romer, 2005). In models based on the wages that encourage efficiency (which depends on the ability of companies to pay them) the solid rigidity of wages is confirmed (Danthine, J.,P., \& Kurmann, A., 2006). In recent studies, wages that encourage efficiency (efficiency wages) and frictional models were increasingly used, in order to explain the context of a dynamic labor 
market. The reason for their use is that the results of researches based on classical models cannot explain the market imbalance (Cahill, 2000).

\section{Conclusion}

„General theory“ can be regarded as a special case of the Classical theory, obtained by imposing certain restrictive assumptions on the latter. Present are two revolutions: the explanation of sustained and substantial unemployment, and attack on the received Theory of Money as a tool for the analysis of short-run problems. In the short run, the "Classical" system adjusts to changes in money expenditures by means of price-level movements while Keynesian adjusts primarily by way of real income movements (production). In short term Keynes considered consumption (saving), investment, and employment are freely variable. The price actually achieved depends upon the amount of information "purchased" (analysis of the behavior of the individual trader at information-gathering). Dynamic properties of an economic system depend upon its "transaction structure", i.e. money. The essence of Keynes' diagnosis of depressions is that actual disequilibrium price vector initiating the contraction differs from the appropriate, hypothetical equilibrium vector in respect that the general level of long-term asset prices is lower than warranted. The question why the rate of interest would not "equalize saving and investment" has been one of the crucial questions of macro-dynamic theory. Keynes assumes that wealth effect affects current consumption in the same direction as the substitution effect. Also that with appropriate institutional arrangements, the interest elasticity of money demand based purely on the "transaction and precautionary motives" would be significantly less. Keynes' speculative demand for money has been all but relinquished by modem theorists as an element of "general" macro-theory. Later economic thought as well as the Keynesian tradition created conviction that Keynes viewed monetary policy as ineffective, but one cannot find such statement by him. Neo-Keynesian economic theory provides alternative answers to the question of wages restrictions (in the case of asymmetry-imperfect information) - socalled wages that encourage efficiency (efficiency wages). In models based on the wages that encourage efficiency (which depends on the ability of companies to pay them) the solid rigidity of wages is confirmed. The reason for use of wages that encourage efficiency (efficiency wages) and frictional models is that the results of researches based on classical models cannot explain the market imbalance.

\section{References}

Bobbio, N.(1992). Liberalism and Democracy, Novi Liber, ISBN 953-6045-23-0, Zg. Cahill, M.B.(2000). Exploring the interaction between efficiency wages and labor market frictions, The Quarterly Review of Economics and Finance, Vol. 40, No.1, ISSN 1062-9769

Cakardic, A.(2006). Global Neo-liberal Democracy in the "Minimal" State, "Reduction of Politics", Philosophical Research, Vol. 26, No. 4, ISSN 1848-2309 
Letunic, S. \& Dragicevic, M.: Leijonhufvud's Interpretation of J.M.Keynes (Monet...

Casares, M., Moreno, A., Vázquez J.(2014). An estimated New-Keynesian Model with Unemployment as Excess Supply of Labor, Journal of Macroeconomics, Vol.39, ISSN 0164-0704

Cate, T.(2013). An Encyclopedia of Keynesian Economics, Second edition, Edward Elgar Publishing, ISBN 978-1-84980-172-0, Northampton

Danthine, J.,P., Kurmann, A.(2006). Efficiency wages revisited: The internal reference perspective, Economics Letters, Vol. 90, No. 2, ISSN 0165-1765

Dupaquier, J., Whitaker, J.,K., Eisermann, G.(2001). International Encyclopedia of the Social \& Behavioral Sciences, Elsevier, ISBN 978-0-08-043076-8, Oxford Galbraith, J.K.(1995). Economics in perspective, Mate, ISBN 978-953-246-062-9,Zg. Hodgson, M.G.(2004). Reclaiming Habit for Institutional Economics, Journal of Economic Psychology, Vol. 25, No.4, ISSN 0167-4870

Lawson, R.A., Clark J.R.(2010). Examining the Hayek-Friedman hypothesis on economic and political freedom, Journal of Economic Behavior \& Organization, Vol. 74, No.3, ISSN 0167-2681

Leijonhufvud, A.(1983). On Keynesian Economics and the Economics of J.M.Keynes, Ekonomska Biblioteka, ISBN 978-8613003762, Zagreb

Leijonhufvud, A.(1968). On Keynesian Economics and the Economics of Keynes: a study in monetary theory, Oxford University Press, ISBN 978-0195009484, USA

Lewbel, A.(1990). Income Distribution Movements and Aggregate Money Illusion, Journal of Econometrics, Vol. 43, No. 1-2, ISSN 0304-4076

Mises, L.v., Hayek, F. A.(1998). About Free Market, Mate, ISBN 978-953-246-062-9, Zagreb

Romer, D.(2005). A.Macroeconomics, McGraw-Hill, ISBN 0-07-231855-4, N.York Samuelson, P.,A.(1988). The Keynes-Hansen-Samuelson multiplier-accelerator model of secular stagnation, Japan and the World Economy, Vol.1, No. 1, ISSN 0922-1425

Schumpeter, A. J.(1975). History of economic analysis, Informator, ISSN 953-170079-6, Zagreb

Sharma, S.(2010). Reflections on the Philosophical Foundations of Economics, Mikrorad, ISBN 978-953-6286-94-2, Zagreb

Swamy, P.(1982). The Rational Expectations Approach to Economic Modeling, Journal of Economic Dynamics and Control, Vol. 4, ISSN 0165-1889

Veljak, L.(2009). Inexorability of Globalization, necessity of an alternative and the question of responsibility, Philosophical research, Vol. 29, No. 113, ISSN 1848-2309 Veljak, L.(2010). Contributions to the critique of false alternatives, Otkrovenje, ISBN 9788683353651, Beograd

Voigt, S.(2001). The legacy of Friedrich von Hayek, Economic Systems, Vol.25, No.4, ISSN 0939-3625

Weil, P.(1989). Why is the risk-free rate so low if agents are so averse to Intertemporal Substitution?, The equity premium puzzle and the risk-free rate puzzle, Journal of Monetary Economics, Vol. 24, No. 3, ISSN 0304-3932 